\title{
СЕРВІС ДЛЯ ВІДДАЛЕНИХ ТЕЛЕМЕДИЧНИХ КОНСУЛЬТАЦІЙ ІЗ ВИКОРИСТАННЯМ ВІРТУАЛЬНИХ МАШИН У ГРІД
}

\author{
О. Ф. Борецький, А. О. Сальніков, Є. А. Слюсар, Ю. В. Бойко \\ Київський національний університет імені Тараса Шевченка
}

\section{SERVICE FOR REMOTE TELEMEDICINE CONSULTATIONS USING VIRTUAL MACHINES IN GRID

\author{
O. F. Boretskyi, A. O. Salnikov, Ye. A. Sliusar, Yu.V. Boyko \\ Taras Shevchenko National university of Kyiv
}

Вступ. Для вирішення сучасних ресурсоємних завдань у різних галузях науки та техніки академічний ГРІД-сегмент було розвинуто до національного рівня (УНГ). Він увійшов до світових ГРІД-інфраструктур, наприклад EGI, та широко застосовується в прикладних проектах у різних галузях. Так, для завдань медичних популяційних досліджень неінфекційних захворювань 3 використанням ГРІД-інфраструктури в Україні було створено проект MedGrid. У рамках даного проекту вже проведено роботи щодо накопичення електрокардіограм у форматі SCP на сховищах даних УНГ з реплікацією та проведення масових досліджень накопичених даних. У результаті співпраці 3 лікарями провідних закладів охорони здоров'я виявилося, що актуальними є завдання проведення аналізу та візуалізації окремих медичних досліджень із можливістю надання віддалених телемедичних консультацій.

Результати та їх обговорення. Авторами запропоновано використати обчислювальні ресурси УНГ для аналізу та візуалізації кардіограм із застосуванням фреймворку Rainbow, що дозволяе запускати апаратно-прискорені віртуальні машини як звичайні ГРІД-завдання. Такий підхід дозволяе отримати доступ до значних обчислювальних потужностей та не переносити дані для аналізу 3 швидкої мережі УНГ до інших ресурсів у мережі Інтернет.

На основі фреймворку Rainbow розроблено PaaS сервіс, що дозволяє запустити віртуальну машину з OC Windows, потрібним прикладним програмним забезпеченням для аналізу та візуалізації кардіограм і отримати інтерактивний доступ по протоколу
RDP. Функціонал сервісу розширено компонентом автоматизації встановлення прикладного програмного забезпечення на етапі запуску віртуальної машини в ГРІД. У такій конфігурації для запуску віртуальної машини користувачу необхідно самостійно сформувати файл опису ГРІД-завдання, в якому вказати вхідні файли та прикладне програмне забезпечення для аналізу і запустити завдання, використавши користувацький ГРІД-сертифікат. Для автоматизації запуску віртуальних машин i надання доступу лікарям, які не мають власного ГРІД-сертифікату та не володіють навиками роботи 3 ГРІД-інфраструктурою, пропонується сервіс для віддалених телемедичних консультацій.

Взаємодія з сервісом відбувається шляхом обміну НTTP-запитами у XML-форматі 3 веб-порталом телемедичних консультацій. Для резервування обчислювальних ресурсів та пришвидшення запуску віртуальних машин використовуються пілотні ГРІД-завдання. Останні при виконанні на кластері звертаються до сервісу, запитують інформацію про завдання й, у разі їх наявності, завантажують та інсталюють необхідне програмне забезпечення, а також завантажують файли медичних досліджень для подальшого оброблення.

Веб-портал запитує інформацію про доступні файли медичних досліджень, доступне прикладне програмне забезпечення (ПЗ) та вільні пілотні ГРІД-завдання. При необхідності проведення віддаленої телемедичної консультації до сервісу надсилається запит із зазначенням необхідного ПЗ та файлів медичних досліджень для оброблення. Сервіс, отримавши запит, використовує вільне пілотне ГРІД-завдання та запускає віртуальну 
МЕДИЧНА ІНФОРМАТИКА

TA ІНЖЕНЕРІЯ

машину з потрібними параметрами та даними. До веб-порталу у відповідь надсилаються параметри для віддаленого підключення по протоколу RDP, що надаються лікарю.

Висновок. Представлено авторську розробку щодо використання обчислювальних ресурсів
ТЕЗИ ІІ-ГО з'їздУ 3 МІЖНАРОДНОЮ УЧАСТЮ «Медична та біологічна інформатика і кібернетика»

УНГ для аналізу та візуалізації медичних досліджень, зокрема кардіограм, із можливістю надання віддалених телемедичних консультацій, із застосуванням фреймворку Rainbow, що дозволяє запускати апаратно-прискорені віртуальні машини як звичайні ГРІД-завдання. 